GEOLOGICA BALCANICA 50 (3), Sofia, December 2021, pp. 3-13.

\title{
The thermal waters in Sofia City (Bulgaria): importance, condition and problems
}

\author{
Vladimir Hristov ${ }^{1}$, Nikolay Stoyanov ${ }^{2}$, Simeon Valchev ${ }^{1}$, Aleksey Benderev ${ }^{1 *}$ \\ ${ }^{1}$ Geological Institute, Bulgarian Academy of Sciences, Acad. G. Bonchev Str., Bl. 24, 1113 Sofia, Bulgaria; \\ e-mails:vhh_gi@abv.bg;nts@mgu.bg; simeonwaltscheff@hotmail.co.uk; alekseybenderev@yahoo.com \\ ${ }^{2}$ University of Mining and Geology "St Ivan Rilski”, 1700 Sofia, Bulgaria \\ * corresponding author
}

(Received: 27 September 2021; accepted in revised form: 29 October 2021)

\begin{abstract}
Sofia, the capital of Bulgaria, is situated in a region rich in thermal waters, which were a major factor for the establishment and development of the city. The thermal spring in the city center of Sofia has been in use since ancient times. As the city expanded rapidly in the $19^{\text {th }}$ and $20^{\text {th }}$ centuries, it absorbed many other sources of thermal water. In addition, the available volume of usable thermal water increased with the construction of abstraction wells. The prevailing types of thermal waters are sourced from Mesozoic rocks at the base of the Sofia graben. The water temperatures are in the range between $21^{\circ} \mathrm{C}$ and $54{ }^{\circ} \mathrm{C}$, and the mineralization is up to approximately $1 \mathrm{~g} / \mathrm{L}$ total dissolved solids (TDS). There is only one source in deeper rock formations with approximately $4 \mathrm{~g} / \mathrm{L}$ TDS. The population of the city utilizes the thermal water resources to a various degree, mainly for bottling of natural mineral water. Some sources are used for balneology, sport, recreation and sanitation; however, their potential is not sufficiently utilized. Considering the importance of the thermal water resources for the city and its population, a numerical model was set up to study the impact of subway construction on the thermal spring in the center of Sofia.
\end{abstract}

Hristov, V., Stoyanov, N., Valchev, S., Benderev, A. 2021. The thermal waters in Sofia City (Bulgaria): importance, condition and problems. Geologica Balcanica 50 (3), 3-13.

Keywords: thermal water, seismic hydrogeology, groundwater modeling, groundwater control, construction dewatering, Sofia (Bulgaria).

\section{INTRODUCTION}

Sofia is one of the few European capital cities with thermal water springs. These are significant for the establishment, existence and development of the city. Currently, there are over 1.2 million inhabitants, who use the mineral waters to a certain degree. The coat of arms of Sofia City includes a symbol representing the mineral waters. The objective of the present study is to review the current status of thermal water in the frame of Sofia City, its importance, condition and problems related to its rational use and preservation for the future generations.

\section{GEOLOGICAL AND HYDROGEOLOGICAL BACKGROUND}

The city of Sofia is located within an intermountain valley (Sofia geothermal basin) covering an area of about $1,180 \mathrm{~km}^{2}$. The Sofia geothermal basin is an elongated graben structure, bounded by the Balkan Mountains to the northeast and the Lyulin, Vitosha and Lozen mountains to the southwest (Antonov and Danchev, 1980). The graben is approximately $60 \mathrm{~km}$ long and 20-25 km wide. The graben basement is composed of various Mesozoic rocks. In the southwestern part, the basement comprises Upper 
Cretaceous andesites, volcanisedimentary and sedimentary rocks; the rest of the basement formations include carbonate and terrigenous rocks of Triassic, Jurassic and Early Cretaceous ages. The graben is filled with Neogene deposits, mainly sands, clays, sandstones and lignite seams at places. The total thickness of the Neogene complex varies from $100 \mathrm{~m}$ to $1,100 \mathrm{~m}$. The thickness of the Quaternary cover is between $50 \mathrm{~m}$ and $100 \mathrm{~m}$.

The graben structure is complicated by many fault displacements that form internal small horsts and depressions. These provide pathways for water circulation and hydraulic connections between different water bodies. Three types of reservoirs are present in the Sofia basin: porous, karstic and fractured. The reservoirs are both within the basement rocks and the Neogene and Quaternary deposits (Antonov and Danchev, 1980; Petrov, 2006).
Their hydrogeological properties are specific to the depth of occurrence, lithological type and structure of the host rocks and the conditions of natural recharge and draining. The geothermal field in the area of Sofia is disrupted by the thermal water flow. Geological, hydrogeological, hydrochemical and geophysical investigations have been carried out by many researchers in an attempt to figure out the processes of thermal water formation in the basin (e.g., Radoslavov, 1918; Azmanov, 1940; Kusitaseva and Melamed, 1958; Shterev, 1964; Petrov et al., 1970; Antonov and Danchev, 1980; Petrov et al., 1996; Pentcheva et al., 1997; Bojadgieva and Gasharov, 2001; Hristov, 2001; Penchev and Velichkov, 2011; Hristov et al., 2016; Trayanova et al., 2018). The thermal field forms a closed zone of enhanced thermal potential on the heat flow map of Bulgaria. The estimated average conductive heat flow is about

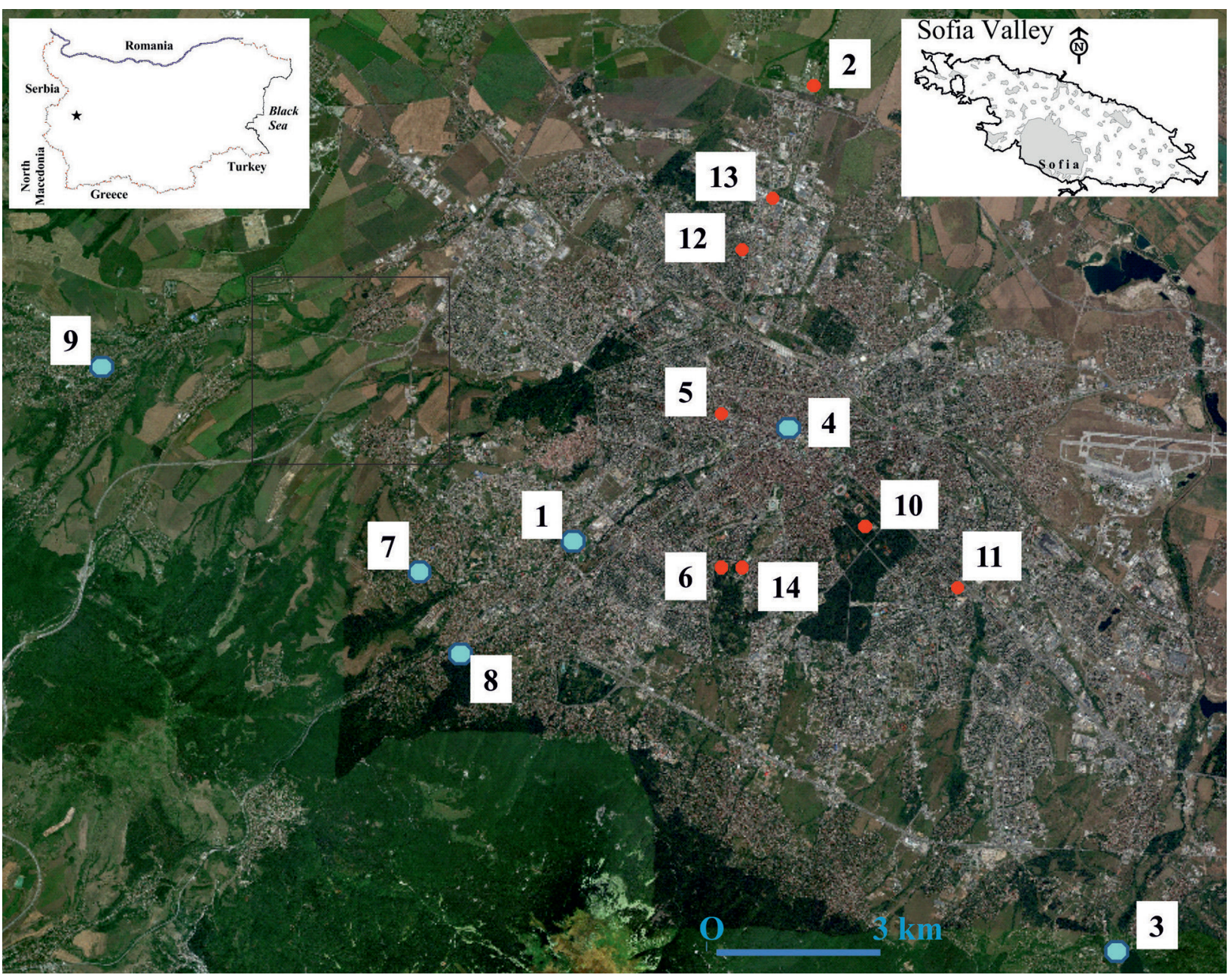

Fig. 1. Location of thermal water sources in Sofia. Springs are shown in blue; abstraction wells in red (map sourced from Google Earth Pro on 20 March 2019). 
$0.08 \mathrm{~W} / \mathrm{m}^{2}$ and the average geothermal gradient is $4.7^{\circ} \mathrm{C} / 100 \mathrm{~m}$ (Bojadgieva and Gasharov, 2001).

The thermal waters in the Sofia lowland are revealed in 75 water abstractions, including several springs, grouped in 31 sources of estimated $300 \mathrm{~L} / \mathrm{s}$ total discharge (Penchev and Velichkov, 2011). Twelve of these sources are within the city boundaries. Apart from these, there are two other sources in the adjacent villages of Bankya and Pancharevo, around which recreational areas were formed and which are considered important for the development of Sofia (Fig. 1, Table 1). Some of the thermal sources (e.g., Ovcha Kupel, Pancharevo, Sofia Center, Gorna Banya, Knyazhevo and Bankya) were initially natural springs only, around which abstraction wells were subsequently drilled in the 1950-1960s. Following the construction of the wells, the yields decreased and some springs dried out completely. The other sources are revealed by wells only.

All thermal sources are attached to faults in the reservoir rocks at the base of the Sofia graben. The only exception is the Lozen thermal source, which comprises water from both the graben basement and the overlying Pliocene aquifer complex of alternating clays, clayey sands and sands. It has been established that the thermal waters are influenced by seismic phenomena. Historical records indicate that a small warm spring existed up to the mid$19^{\text {th }}$ century in Ovcha Kupel. In 1858, a devastating earthquake occurred in Sofia and a fracture was formed, from which a fountain of water appeared. Subsequently, the yield gradually decreased but remained higher than the yield in the time prior to the earthquake. Petrov (1983) published data on the impact of the earthquake that occurred on 4 March 1977 in Vrancea, Romania. Following the event, the yield of the thermal spring in the center of Sofia rapidly increased from $16.7 \mathrm{~L} / \mathrm{s}$ to $18.7 \mathrm{~L} / \mathrm{s}$ and, weeks after the main shock, it peaked at $24 \mathrm{~L} / \mathrm{s}$. The spring continued to discharge at an elevated rate for years after the earthquake. Likewise, changes in yield were recorded at the thermal springs in Gorna Banya and Bankya. Near one of the thermal springs in Pancharevo, a small cold spring was observed to repeatedly start discharging and warm up to $27^{\circ} \mathrm{C}$. Changes in yield were reported in relation to other seismic events, e.g., in 1917, 1928 (Radoslavov, 1928; Boyadzhiev, 1922; Petrov et al., 1996). The latest event was recorded in the Lozenets source zone, where water started springing from a borehole one day before a magnitude 4 earthquake that occurred in Pernik on 14 September 2017.

Sources of thermal water in Sofia (Petrov et al., 1996; Penchev and Velichkov, 2011)

\begin{tabular}{|c|c|c|c|c|c|c|c|c|}
\hline & Location & $\begin{array}{l}\text { Reservoir } \\
\text { Rocks }\end{array}$ & $\begin{array}{l}\text { Geol. } \\
\text { Index }\end{array}$ & $\begin{array}{l}\text { Flow } \\
\text { Rate, } \\
\mathrm{dm}^{3} / \mathrm{s}\end{array}$ & $\begin{array}{l}\mathrm{T} \\
{ }^{\circ} \mathrm{C}\end{array}$ & $\begin{array}{l}\text { TDS, } \\
\text { g/L }\end{array}$ & $\mathrm{pH}$ & Type \\
\hline 1. & Ovcha Kupel & limestones & $\mathrm{T}_{2}$ & 4.50 & 32 & $1.00-1.30$ & $7.1-7.6$ & $\mathrm{SO}_{4}-\mathrm{HCO}_{3}-\mathrm{Ca}-\mathrm{Na}$ \\
\hline 2. & Ilientsi & limestones & $\mathrm{T}_{2}$ & 0.30 & 47 & $4.14-4.60$ & 8.6 & $\mathrm{HCO}_{3}-\mathrm{Na}$ \\
\hline 3. & Pancharevo & limestones & $\mathrm{T}_{2}$ & 14.70 & $39-49$ & $0.39-0.50$ & 7.8 & $\mathrm{HCO}_{3}-\mathrm{Mg}-\mathrm{Ca}$ \\
\hline 4. & Sofia-Centre & marls & $\mathrm{K}_{2}$ & 20.00 & 46 & $0.28-0.33$ & 9.6 & $\mathrm{HCO}_{3}-\mathrm{SO}_{4}-\mathrm{Na}$ \\
\hline 5. & Batalova Vodenitsa & andesites & $\mathrm{K}_{2}$ & 11.60 & 44 & 0.27 & 8.8 & $\mathrm{HCO}_{3}-\mathrm{SO}_{4}-\mathrm{Na}$ \\
\hline 6. & $\begin{array}{l}\text { Lozenetz Lower } \\
\text { Level }\end{array}$ & $\begin{array}{l}\text { quartz- } \\
\text { diorites }\end{array}$ & $\mathrm{K}_{2}$ & 15.00 & $35-48$ & $0.27-0.34$ & $8.0-9.5$ & $\mathrm{HCO}_{3}-\mathrm{SO}_{4}-\mathrm{Na}$ \\
\hline 7. & Gorna Banya & andesites & $\mathrm{K}_{2}$ & 7.48 & $33-42$ & $0.12-0.17$ & $9.2-10.2$ & $\mathrm{HCO}_{3}-\mathrm{SO}_{4}-\mathrm{Na}$ \\
\hline 8. & Knyazhevo & andesites & $\mathrm{K}_{2}$ & 7.42 & $21-32$ & $0.11-0.16$ & $9.4-10.0$ & $\mathrm{HCO}_{3}-\mathrm{SO}_{4}-\mathrm{Na}$ \\
\hline 9. & Bankya & andesites & $\mathrm{K}_{2}$ & 31.00 & $24-38$ & $0.26-0.30$ & $9.2-10.0$ & $\mathrm{HCO}_{3}-\mathrm{SO}_{4}-\mathrm{Na}$ \\
\hline 10. & Republica Plazh & andesites & $\mathrm{K}_{2}$ & 3.64 & 39 & 0.33 & 8.5 & $\mathrm{HCO}_{3}-\mathrm{SO}_{4}-\mathrm{Na}$ \\
\hline 11. & Sofia $4^{\text {th }} \mathrm{km}$ & andesites & $\mathrm{K}_{2}$ & 5.86 & 35 & 0.34 & 9.3 & $\mathrm{HCO}_{3}-\mathrm{SO}_{4}-\mathrm{Na}$ \\
\hline 12. & Nadezhda & $\begin{array}{l}\text { marls and } \\
\text { sandstones }\end{array}$ & $\mathrm{K}_{2}$ & 6.94 & $53-54$ & $1.60-1.64$ & 8.3 & $\mathrm{HCO}_{3}-\mathrm{SO}_{4}-\mathrm{Na}$ \\
\hline 13. & $\begin{array}{l}\text { Svoboda District } \\
\text { Sofia }\end{array}$ & $\begin{array}{l}\text { marls and } \\
\text { sandstones }\end{array}$ & $\mathrm{K}_{2}$ & 7.20 & 50 & 1.91 & 8.2 & $\mathrm{HCO}_{3}-\mathrm{SO}_{4}-\mathrm{Na}$ \\
\hline 14. & $\begin{array}{l}\text { Lozenetz Upper } \\
\text { Level }\end{array}$ & sands & $\mathrm{N}_{2}$ & 6.80 & 24 & 0.94 & 7.7 & $\mathrm{HCO}_{3}$-Ca-Mg \\
\hline
\end{tabular}

The thermal spring in the center of Sofia (marked as No. 4 in Fig. 1) is most important for the founding and development of the city (Petrov et al., 1970; Petrov et al., 1996; Hristov and Bojadzhieva, 2006; Penchev and Velichkov, 2011). The spring is related to the fractures of two normal faults in the most elevated block in the Sofia graben, which are mutually perpendicular with NW and SE strikes. The Upper Cretaceous andesite rocks and sedimentary deposits are at a depth of approximately $30 \mathrm{~m}$ below the Quaternary and Neogene cover. 


\section{SIGNIFICANCE OF THE THERMAL WATERS IN THE CITY OF SOFIA}

The thermal spring in the center of Sofia (marked as No. 4 in Fig. 1) is most important for the founding and development of the city (Petrov et al., 1970, 1996; Hristov and Bojadzhieva, 2006; Penchev and Velichkov, 2011). The spring is related to the fractures of two normal faults in the most elevated block in the Sofia graben, which are mutually perpendicular with NW and SE strikes. The Upper Cretaceous andesite rocks and sedimentary deposits are at a depth of approximately $30 \mathrm{~m}$ below the Quaternary and Neogene cover.

In the distant past, the Celtic tribe Serdi settled around a natural thermal spring (now called Sofia Center Spring) in II-I century BC and the main settlement in the area, Serdica, was named after them. The thermal spring is within the boundaries of the ancient settlement (Fig. 2). The town reached its peak during antiquity when it became a very famous populated place of the Eastern Roman Empire during the reign of Emperor Constantine the Great
(306-337 AD). According to P. Petrov (in: Penchev and Velichkov, 2011), accounts of the thermal spring in Sofia date back to 2,400 years before present. The first spring catchment was constructed by the Romans in the II-I c. BC and destroyed in the earthquake of $55 \mathrm{AD}$. It was rebuilt in $79 \mathrm{AD}$ during the reign of Emperor Trajan. After 395 AD, the city was called Triaditsa by the Byzantines and Sredets by the Slavs. The greater part of the ancient city is now buried under the present public and residential buildings. In 1430, the Ottomans built a wooden structure, which was destroyed by an earthquake in 1573 and subsequently reconstructed several times. A bathhouse was built next to it.

After Bulgaria gained its independence, the spring area was remodeled in 1892, partially utilizing the old Roman structure. In 1906, a public bathhouse was built and became one of the symbolic buildings of the city, now listed as national heritage. In 1953-1955, a vertical concrete shaft was designed to reach for the first time down to the bedrock at $28.3 \mathrm{~m}$ depth. It almost fully penetrates and seals the cooler groundwater in the overlying

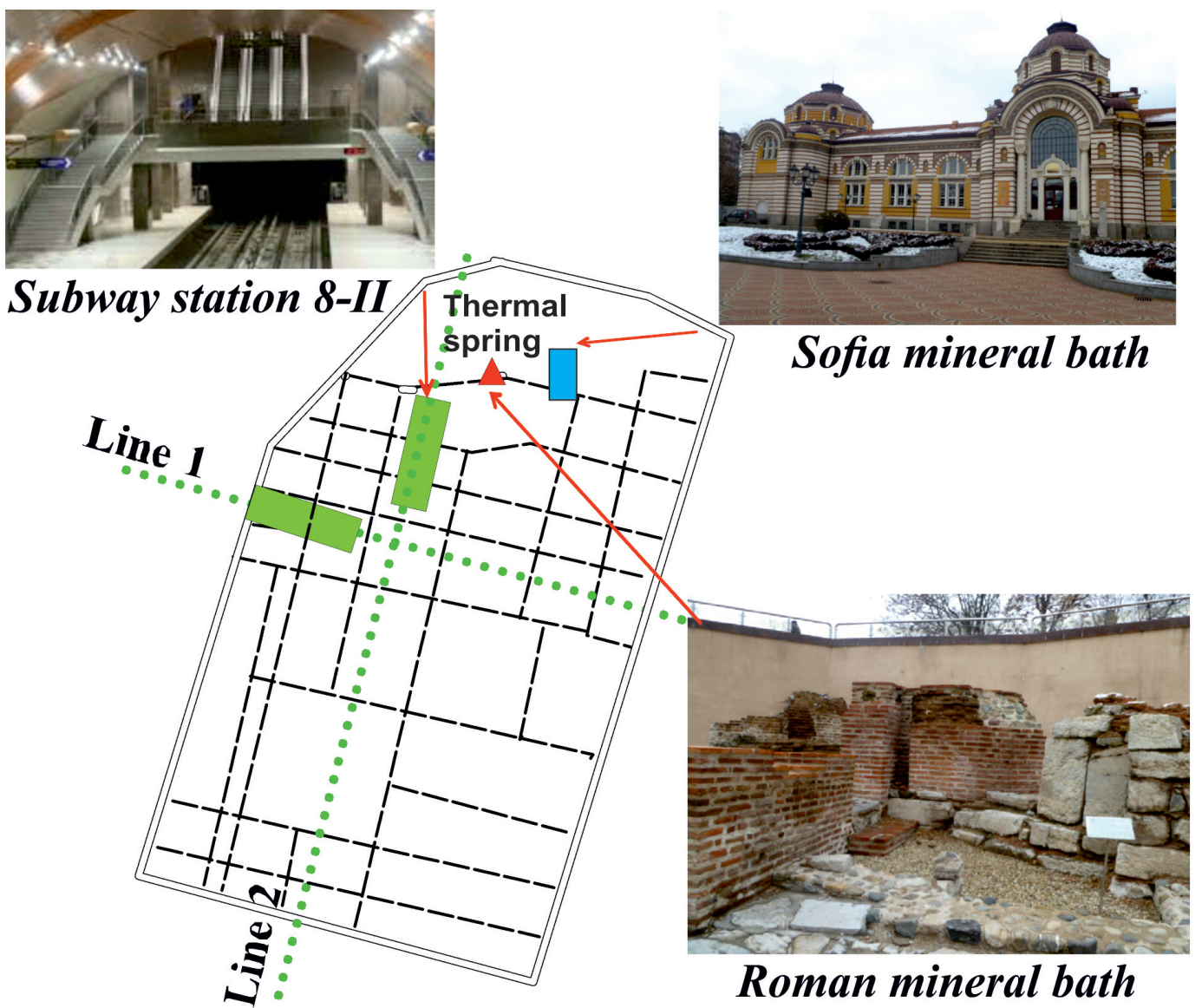

Fig. 2. Sketch of the antique town of Serdica and Sofia subway lines. 
Neogene-Quaternary complex. In 1988, the bathhouse closed down and was converted to Regional Historical Museum. At present, the thermal water is partially diverted to a fountain complex, where the people of Sofia freely fill in their bottles with mineral water of good drinking quality; the water is of very low mineralization and high $\mathrm{pH}$. The fountain complex and archaeological remains of the Roman and Turkish baths are one of the tourist attractions in Sofia (Fig. 2).

In the beginning of the $20^{\text {th }}$ century, Sofia City expanded rapidly, which brought about more active utilization of the thermal waters from the other natural sources. The water was used mainly for sanitation and laundering. Public bathhouses opened in Ovcha Kupel, Gorna Banya, Bankya and Pancharevo. In recent years, the public baths lost their significance and many of the bathhouses are abandoned and derelict. A typical example is the thermal water source in Ovcha Kupel, where a balneology complex was built in 1933. From 1949, it hosted the National Institute for Spa Treatment and Physiotherapy and it was the research center for thermal and mineral waters in Bulgaria. The institute was dissolved by 1993. At present, its successor is the National Specialized Hospital for Physical Therapy and Rehabilitation. Currently, there are balneology centers in the recreational areas in Pancharevo and Bankya. Previous studies (Vladeva and Kostadinov, 1996) show that the thermal waters from the various sources could be appropriate for treatment and prevention of gastro-intestinal and urological conditions, disorders of the joints, liver and gall malfunctions, metabolism problems, intoxication and others.

The thermal waters from sources without natural springs but abstracted only from wells are being used for various purposes, e.g., warm water supply to schools, sports facilities, industrial facilities, swimming pools, recreation. Bottling of mineral water is important for three of the largest sources of thermal waters in Sofia. Currently, there are five concessions in place: two for Gorna Banya (210,166 m³year in total), two for Knyazhevo $\left(18,268 \mathrm{~m}^{3} /\right.$ year in total), and one for Bankya $\left(182,750 \mathrm{~m}^{3} /\right.$ year$)$.

\section{IMPACT OF URBAN ENVIRONMENT ON THE THERMAL WATERS}

One important characteristic of thermal waters is their relatively low vulnerability as they form at greater depths. In this respect, direct impact could only occur at the locations of their discharge to the surface. Such cases have been observed mainly at the Sofia Centre spring catchment, where there is the risk of mixing with cooler shallow groundwater in the Neogene-Quaternary deposits and the risk posed by human activities in the immediate surroundings.

Other risks are related to drilling works close to the sources of thermal water. In the second half of the $20^{\text {th }}$ century, intense drilling was carried out around natural sources of thermal water with the objective of increasing the abstracted volumes. The experience from that period shows that the impacts were only temporary. In general, either the natural springs disappear or the yields decrease. Negative effects on adjacent sources are possible in the events of more significant head depressions. It has been suggested that such a connection existed between the Sofia Center spring, Batalova Vodenitsa and Lozenets Lower Level (Penchev and Velichkov, 2011). Hydraulic connection has been established between the sources of thermal water Nadezhda and Svoboda.

The construction of the Sofia subway was a significant infrastructure project and it was necessary to estimate the impact on the sources of thermal waters. In this regard, the situation around the Sofia Center spring was considered most complicated as at this location the crossing of two subway lines had to be constructed, with the lower line located at a depth of $24 \mathrm{~m}$ below ground level. The complex hydrogeological conditions and the shallow groundwater levels in Sofia posed serious challenges to the construction works. In the course of construction, it was necessary to maintain significant local depression zones, which could cause considerable regional depressions and deformations of the piezometric field. This could result in operational changes for the abstraction facilities for fresh and mineral water. One of the deepest subway sections, Subway Station 8-II, is located only 15-20 m away from the Sofia Center spring (Fig. 3). The risk posed by the construction thereof was evaluated using 3D modeling (Stoyanov, 2019). Subject of investigation were parts of the thermal water reservoir in the volcanisedimentary complex and the overlying NeogeneQuaternary aquifer. A numerical 3D model was set up to simulate the hydrogeological conditions in the pre-construction and construction periods, using the Modflow software (McDonald and Harbaugh, 1988; Anderson et al., 2015; Stoyanov, 2011, 2019). The area of the model domain is $2 \mathrm{~km}^{2}$ and its depth varies between $100 \mathrm{~m}$ and $150 \mathrm{~m}$ (Fig. 3). The geological succession includes two main aq- 

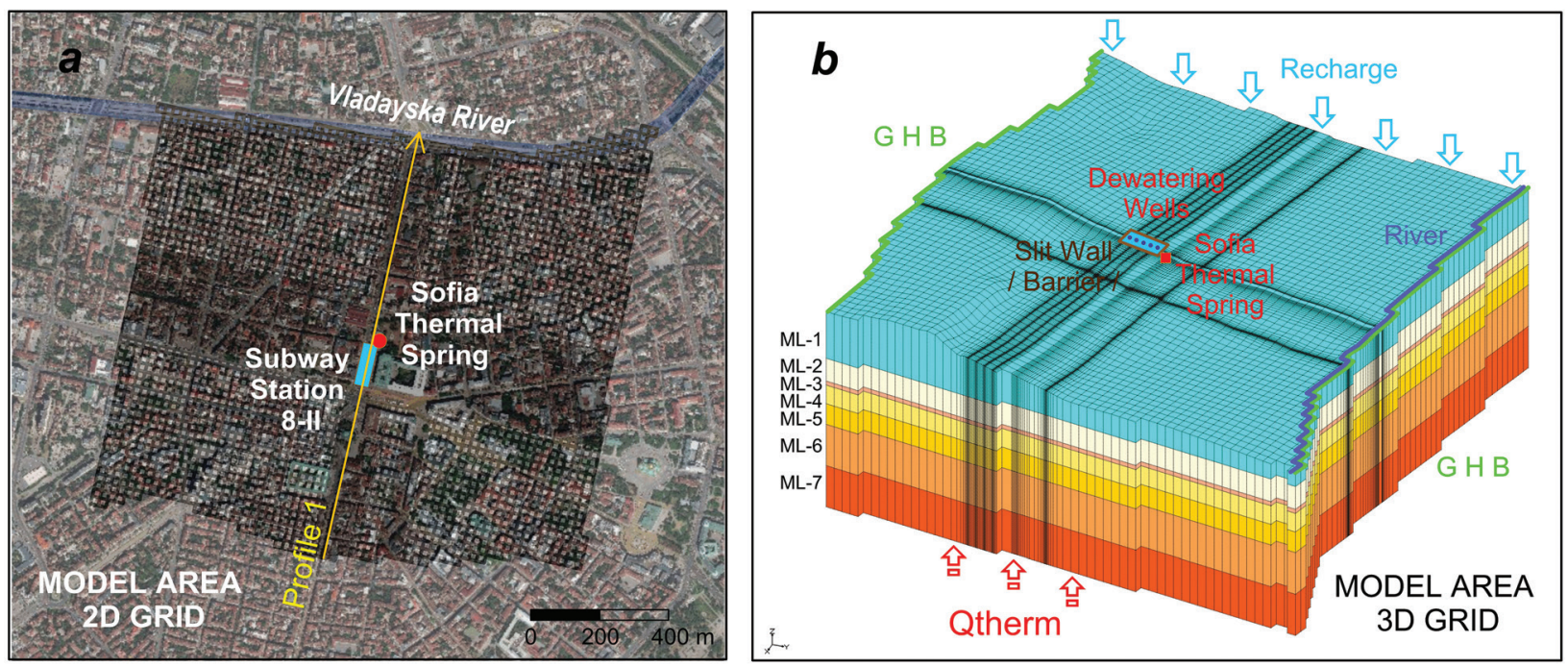

Fig. 3. Model domain: $a$ ) satellite image of the studied site; $b$ ) model layers and boundary conditions.

Table 2

Hydrogeological units (HGU) at the location of the Sofia mineral water spring

\begin{tabular}{c|l|l|c|c}
\hline Higher Order HGU & \multicolumn{1}{|c|}{ Lower Order HGU } & Index & Reservoir Characteristics \\
\hline \multirow{4}{*}{\begin{tabular}{c} 
Neogene-Quaternary aquifer $\begin{array}{c}\text { Quaternary aquifer complex } \\
\text { complex }\end{array}$ \\
\cline { 2 - 4 }
\end{tabular}} & $\begin{array}{l}\text { Pliocene aquifer } \\
\text { level }\end{array}$ & $\begin{array}{l}\text { Intermediate low perme- } \\
\text { ability layer }\end{array}$ & Qaq & Gravel, sand and clay \\
\cline { 2 - 4 } & $\begin{array}{l}\text { Lower layer of very low } \\
\text { permeability }\end{array}$ & $\mathrm{N}_{2} \mathrm{aq}-\mathrm{m}$ & Clayey sand and sandy clay \\
\hline \multirow{2}{*}{$\begin{array}{c}\text { Upper Cretaceous volcanisedi- } \\
\text { mentary aquifer complex }\end{array}$} & Highly permeable zone & Sandy clay and silty clay \\
\cline { 2 - 5 } & Zone of lower permeability & $\mathrm{Cr}_{2} \mathrm{cmx}-1$ & Tectonic zone \\
\cline { 2 - 5 } & Zone of very low permeability & $\mathrm{Cr}_{2} \mathrm{cmx}-2$ & Fractured and altered rock \\
\hline
\end{tabular}

uifer complexes comprising eight hydrogeological units of different order (Table 2).

The aquifer layers in the Neogene-Quaternary complex are hydraulically connected. The groundwater flow is to the north-northeast, the average hydraulic gradient being 0.0056 . Recharge occurs through infiltration from the surface, lateral flow along the SSW boundary and vertical flow from the deeper levels of the Upper Cretaceous complex.

The Sofia Center spring is a focal discharge of groundwater flow originating from a depth of 700-800 $\mathrm{m}$. The thermal mineral water flows along a fault structure with NW-SE strike (Fig. 4). The vertical flow occurs along one or more highly permeable tectonic discontinuities concentrated in the spring zone. In the distant past, before the spring had been captured, the thermal water mixed with the cooler groundwater in the Neogene-Quaternary deposits and discharged to the ground surface. In the contemporary spring shaft, the elevation of the water intake is at $532.3 \mathrm{~m}$ above sea level and the yield is $16 \mathrm{~L} / \mathrm{s}$. The base of the shaft is $2 \mathrm{~m}$ above the bedrock and it does not fully collect the uplifting thermal water flow; a small portion of the flow infiltrates in the Neogene-Quaternary deposits. The groundwater in the Neogene-Quaternary and the vertical thermal water flow form one single hydraulic system. This means that any considerable impact on the filter bed has the potential of causing notable changes in the entire system.

Subway Station 8-II was constructed in levels, five of which are below the groundwater table. The time for rough construction of each level was 21 days. The elevations of the foundation slabs are at $537.0 \mathrm{~m}, 533.5 \mathrm{~m}, 530.0 \mathrm{~m}, 526.5 \mathrm{~m}$ and $522.2 \mathrm{~m}$ above sea level. The ingress of water in the con- 

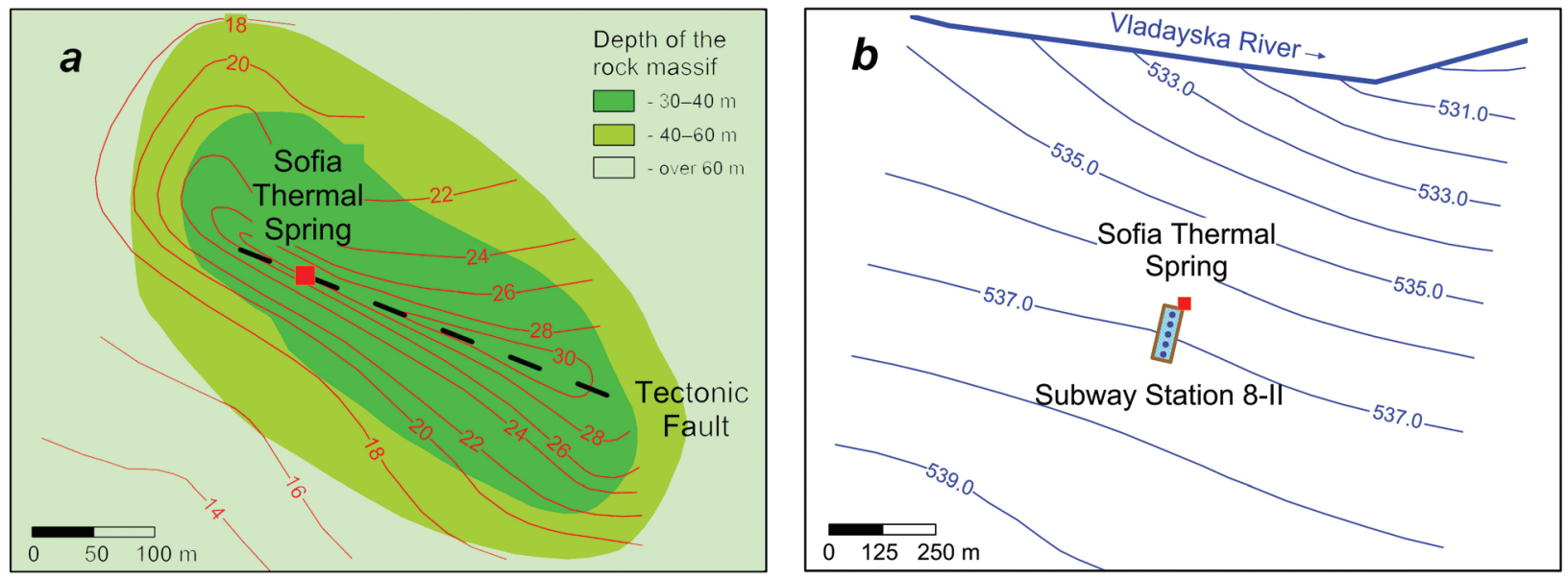

Fig. 4. Hydrogeological setting in the studied area: $a$ ) geothermal map and depth of the rock basement; $b$ ) contour map of the natural groundwater flow conditions.

struction pit was limited by a slurry wall of $40 \mathrm{~m}$ depth, $0.8 \mathrm{~m}$ width and $1 \times 10^{-8} \mathrm{~cm} / \mathrm{s}$ permeability. The dewatering system included five dewatering wells up to $34 \mathrm{~m}$ in depth and $800 \mathrm{~mm}$ in diameter. The dewatering system had to operate continuously for 470 days in total, in six pumping stages, depending on the construction schedule and the depth of the different foundation levels.

The model comprised 7 layers and 12 zones representing the hydrogeological units of different order identified in the geological sequence (Fig. 3, Table 3). The top of the upper layer in the model was defined by the ground surface, while the base of each layer was defined by horizontal planes. Hy- draulic conductivities $(k)$ and storage coefficients $(S)$ are specified in Table 3. The lateral vs. vertical anisotropy in hydraulic conductivity is assumed to be $k_{x}=k_{y}=10 k_{z}$, which is a commonly observed ratio for deep hydrogeological units. Isotropic hydraulic conductivity was assumed for the $\mathrm{Cr}_{2} \mathrm{cmx}-1$ zones only. The regional groundwater flow was simulated by assigning a general head boundary (GHB) conditions on the southwestern and northeastern model boundaries (Fig. 3). Software package River was used to simulate the Vladayska River in the top layer. Infiltration from the surface was modeled as constant uniform recharge of $1.5 \times 10^{-4} \mathrm{~m} / \mathrm{d}$. The vertical flow of thermal water $Q t$ was modeled with the

Table 3

Model parameters of the layers and zones

\begin{tabular}{|c|c|c|c|c|c|}
\hline \multirow{2}{*}{ Model Layer } & \multirow{2}{*}{ Base Elevation } & \multirow{2}{*}{ Model Zone } & \multirow{2}{*}{ HGU Index } & \multicolumn{2}{|c|}{ Hydrogeological Parameters } \\
\hline & & & & $k, \mathrm{~m} / \mathrm{d}$ & $S,-$ \\
\hline ML-1 & 530 & - & Qaq & 5.50 & 0.150 \\
\hline ML-2 & 514 & - & $\mathrm{N}_{2}$ aq-up & 1.00 & 0.050 \\
\hline ML-3 & 512 & - & $\mathrm{N}_{2} \mathrm{aq}-\mathrm{m}$ & 0.50 & 0.020 \\
\hline \multirow{3}{*}{ ML-4 } & \multirow{3}{*}{503} & MZ-4.1 & $\mathrm{N}_{2} \mathrm{aq}-\mathrm{m}$ & 0.50 & 0.020 \\
\hline & & MZ-4.2 & $\mathrm{Cr}_{2} \mathrm{cmx}-2$ & 0.25 & 0.005 \\
\hline & & MZ-4.3 & $\mathrm{Cr}_{2} \mathrm{Cmx}-1$ & 150.00 & 0.250 \\
\hline \multirow{3}{*}{ ML-5 } & \multirow{3}{*}{493} & MZ-5.1 & $\mathrm{N}_{2} \mathrm{aq}-\mathrm{m}$ & 0.50 & 0.020 \\
\hline & & MZ-5.2 & $\mathrm{Cr}_{2} \mathrm{cmx}-2$ & 0.25 & 0.005 \\
\hline & & MZ-5.3 & $\mathrm{Cr}_{2} \mathrm{cmx}-1$ & 150.00 & 0.250 \\
\hline \multirow{3}{*}{ ML-6 } & \multirow{3}{*}{473} & MZ-6.1 & $\mathrm{N}_{2} \mathrm{aq}-\mathrm{m}$ & 0.50 & 0.020 \\
\hline & & MZ-6.2 & $\mathrm{Cr}_{2} \mathrm{cmx}-3$ & 0.10 & 0.003 \\
\hline & & MZ-6.3 & $\mathrm{Cr}_{2} \mathrm{cmx}-1$ & 150.00 & 0.250 \\
\hline \multirow{3}{*}{ ML-7 } & \multirow{3}{*}{453} & MZ-7.1 & $\mathrm{N}_{2} \mathrm{aq}-\mathrm{l}$ & 0.20 & 0.010 \\
\hline & & MZ-7.2 & $\mathrm{Cr}_{2} \mathrm{cmx}-3$ & 0.10 & 0.003 \\
\hline & & MZ-7.3 & $\mathrm{Cr}_{2} \mathrm{cmx}-1$ & 150.00 & 0.250 \\
\hline
\end{tabular}




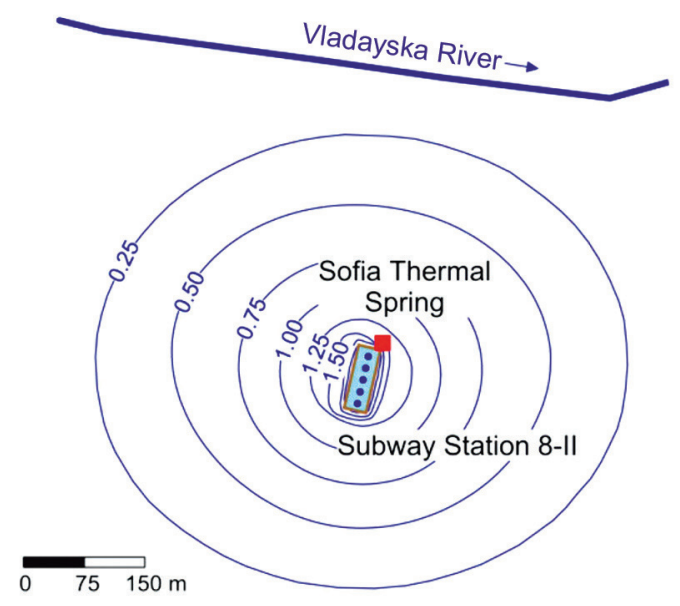

Fig. 5. Contour map of the cone of depression at the end of the construction period.

Specified Flow package by assigning a loss in model zone MZ-7.3, which was calibrated to the head and discharge rates of the spring. The spring was simulated by Specified Head at $523.3 \mathrm{~m}$, the elevation of the water intake in the shaft. The slurry wall was simulated using the Horizontal Flow Barrier package as a tridimensional object with the actual dimensions and transmissivity $T_{b}=1.1 \times 10^{-5} \mathrm{~d}^{-1}$. Varying abstraction rates were used for the dewatering wells. The overall dewatering period during the six construction stages was split into 11 stress periods. The pumping schedule of the wells was optimized by running different model scenarios.

The system was found to be most efficient when the wells operated at equal pumping rates, varied in the first five stages and kept constant in the final stage. In the final dewatering stage, the modeled piezometric depression spread over an area of approximately $1.65 \mathrm{~km}^{2}$, where the modeled drop in pressure was generally between $0.25 \mathrm{~m}$ and 1.0 $\mathrm{m}$ and reaching up to $2-3 \mathrm{~m}$ in the immediate surroundings of the construction pit (Fig. 5).

The modeled head distribution in the cross section along Profile 1 (Fig. 3) is shown in Fig. 6a-d, where the natural piezometric surface in the area of the Sofia Center spring, before dewatering is presented (Fig. 6a), and the modeled piezometric changes after 30, 60 and 470 days of dewatering (Fig. 6b-d) are present. The model solution for the optimal dewatering schedule is presented in Fig. 7.

The water balance produced by the model indicated that the pumped water was being compensated mainly from increased inflow from the southern Neogene-Quaternary complex, as well as from decrease in static and elastic storage. At the same time, the inflow into the Vladayska River and the groundwater flow to the north were reduced. As a result of these changes, the modeled discharge from the spring also decreased, correspondingly to the dewatering stages (Fig. 8).

The analysis of the model results indicated that the yield of the Sofia Center spring would decrease by $1.6 \mathrm{~L} / \mathrm{s}$ in the initial stages of groundwater dewatering and further decrease by $2.4 \mathrm{~L} / \mathrm{s}$, or $15 \%$ of the average discharge, during the continuous pumping in the final stage, until the completion of the dewatering.

\section{CONCLUSION}

The thermal waters in Sofia City are of considerable importance to the city and its inhabitants. The spring in the center of Sofia is the main reason for the establishment and long history of the city and its significance remains in the present times. Many archeological remains from Roman and Medieval times indicate that it has been widely used for sanitation and health maintenance. Within the city boundaries, there are a series of other thermal water sources, which have also left their mark on the development of the city. Some of them have been known since ancient times as natural thermal water springs, while others were revealed by drilling in the $20^{\text {th }}$ century. The utilization of thermal waters is considered insufficient nowadays. Currently, the widest use of the water resources is bottling of natural mineral water (Gorna Banya, Bankya and Knyazhevo). Besides, people in Sofia still keep up with the tradition of using potable water from the thermal water sources in Sofia Center, Knyazhevo, Gorna Banya and Bankya. Opportunities for balneology and recreational use exist in Pancharevo and Bankya. The rest of the sources have been used

Fig. 6. Modeled head in cross section along Profile 1: $a$ ) before dewatering; $b$ ) after 30 days of dewatering; $c$ ) after 90 days of dewatering; $d$ ) after 470 days of dewatering. 

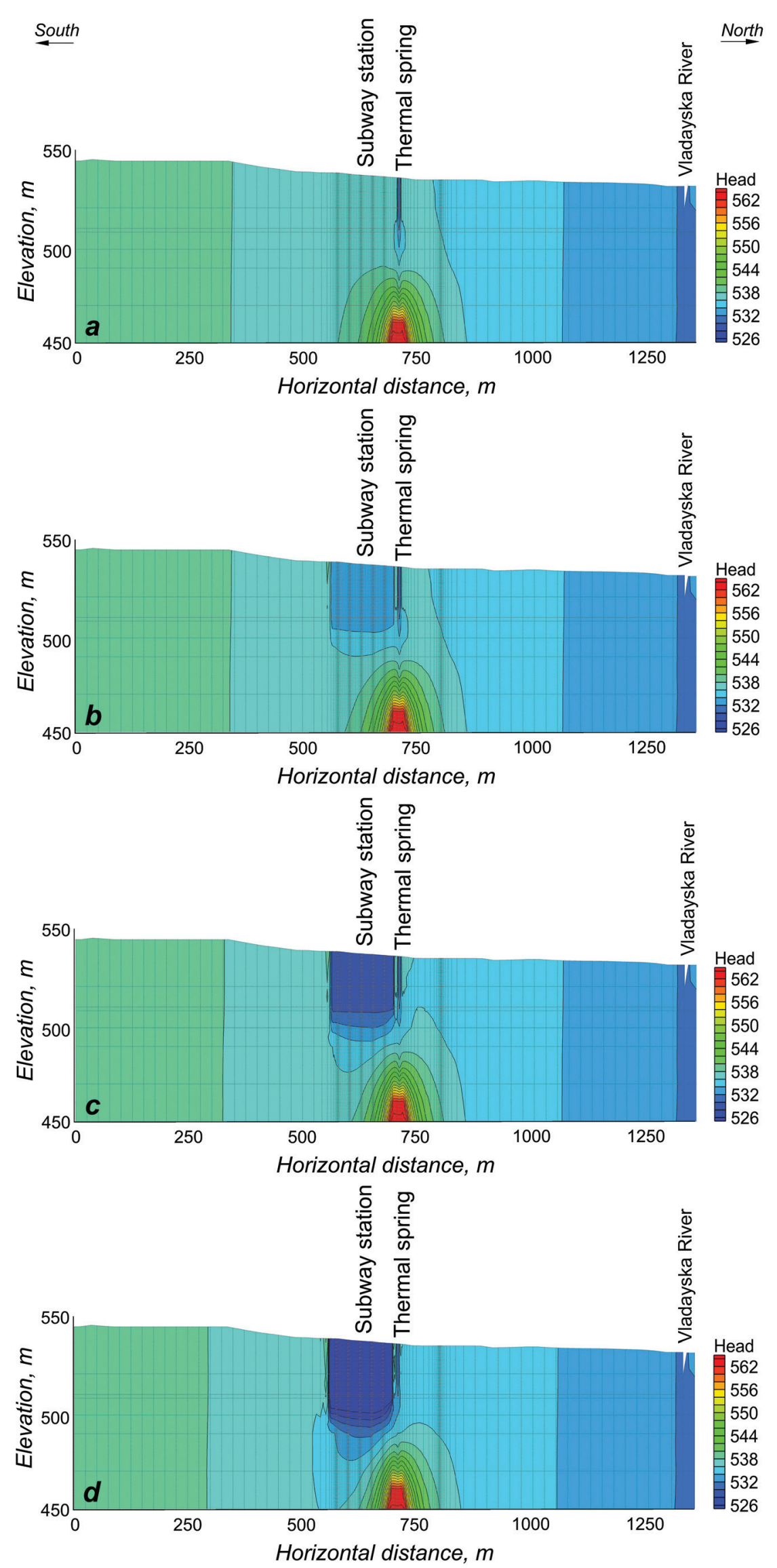


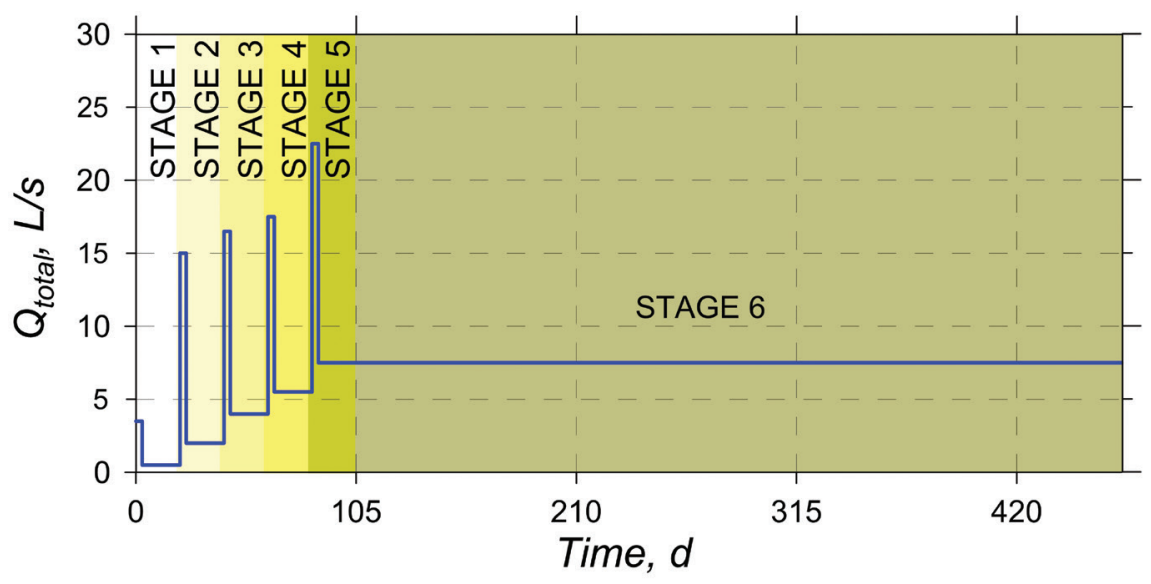

Fig. 7. Stages of dewatering.

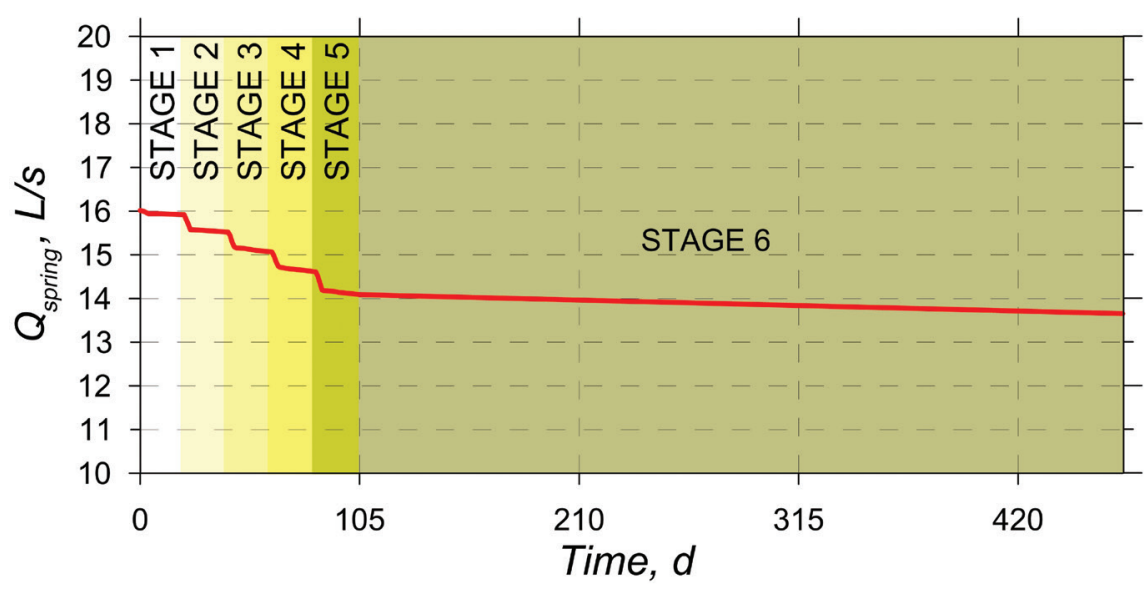

Fig. 8. Decrease in yield of the Sofia Center spring.

only intermittently. In recent years, more attention is being paid to utilizing the thermal waters for recreational activities, sport, healing, as well as a source of thermal energy. In this respect, Sofia Municipality is trying to attract the attention of business circles and foreign investors.

The protection of the thermal water resources is very important, along with utilizing their potential. In most cases, the urban environment has a little impact on the thermal waters; however, the construction of the Sofia subway system as a large infrastructure project had the potential for negative consequences for the natural factors that led to the formation of the thermal spring, which is most important for the city. The presented model evaluations and predictions were confirmed in the course of construction of the subway section adjacent to the Sofia Center spring.

\section{REFERENCES}

Anderson, M.P., Woessner, W.W., Hunt, R.J. 2015. Applied groundwater modeling: simulation of flow and advective transport. Amsterdam, Boston, Heidelberg, London, New York, Oxford, Paris, San Diego, San Francisco, Singapore, Sydney, Tokyo, Elsevier Academic press, 720 pp.

Antonov, H., Danchev, D. 1980. Groundwater in People's Republic of Bulgaria. Tehnika, Sofia, 359 pp. (in Bulgarian).
Azmanov, A. 1940. Bulgarian Mineral Springs. State printing house MTPT, Sofia, 260 pp. (in Bulgarian).

Bojadgieva, K., Gasharov, S. 2001. Catalogue of Geothermal Data of Bulgaria. Gorex Press, Sofia, 163 pp. (in Bulgarian).

Boyadzhiev, K. 1922. Influence of the 1917 earthquake on the mineral water system in Sofia region. Journal of the Bul- 
garian Society of Engineers and Architects 3 (23), 5-6 (in Bulgarian).

Hristov, V. 2001. Application of chemical geothermometers and helium method to low temperature fields and geothermal structure in Southern Bulgaria. PhD thesis, Geological Institute, Bulgarian Academy of Sciences, Sofia, 187 pp. (in Bulgarian).

Hristov, V., Benderev, A., Bojadgieva, K. 2016. Assessment of hydrogeological conditions and geothermal application in Sofia Municipality (Bulgaria). Proceedings of the $2^{\text {nd }} I A H$ Central European Groundwater Conference "Groundwater risk assessment in urban areas”, Bucharest, 36-44.

Hristov, V., Bojadgieva, K. 2006. The mineral water spring in the centre of Sofia. Mining and Geology 1, 18-20 (in Bulgarian).

Kusitaseva, V., Melamed, Y. 1958. Composition of Bulgarian Mineral Waters. Medicine and Sports, Sofia, 280 pp. (in Bulgarian).

McDonald, M., Harbaugh, A. 1988. A Modular Three-Dimensional Finite-Difference Ground-Water Flow Model. US Geological Survey, Techniques of Water Resources Investigations 6-A1, 586 pp., https://doi.org/10.3133/twri06A1.

Penchev, P., Velichkov, V. 2011. Fields of Mineral Water in the Region of Sofia. Sofia Municipality BAPV, Sofia, 43 pp. (in Bulgarian).

Pentcheva, E., Van'tDack, L., Veldeman, E., Hristov, V., Gijbels, R. 1997. Hydrogeochemical Characteristics of Geothermal Systems in South Bulgaria. Universiteit Antwerpen Press, Antwerpen, 121 pp.

Petrov, P. 1983. Hydrogeological phenomena triggered by the earthquake (seismo hydrogeological phenomena). In: Brankov, G. (Ed.), The Earthquake in Vrancea in 1977. Consequence in the Republic of Bulgaria. Bulgarian Academy of Sciences Press, Sofia, 96-111(in Bulgarian).

Petrov, V. 2006. Hydrogeological characteristics of the Pliocene aquifer on the territory of the Sofia Valley. $\mathrm{PhD}$ thesis, University of Mining and Geology “St Ivan Rilski”, Sofia, 137 pp. (in Bulgarian).
Petrov, P., Martinov, S., Limonadov, K., Straka, J. 1970. Hydrogeological Study on Mineral Waters in Bulgaria. Tehnika, Sofia, 196 pp. (in Bulgarian).

Petrov, P., Yotov, I., Gasharov, S., Hristov, V., Benderev, A. 1996. Hydrogeothermal conditions of the Sofia Basin. Report by the Geological Institute at the Bulgarian Academy of Science to the Ministry of Environment and Water, commission No. 69, 06.04.1998. Reassessment of the geothermal energy resources. National Geological Fund, Ministry of Energy, Bulgaria, 60 pp. (in Bulgarian).

Radoslavov, B. 1918. Mines, Quarries and Mineral Waters in Sofia District. Sofia Standing District Commission, Sofia, 169 pp. (in Bulgarian).

Radoslavov, B. 1929. Impact of earthquakes in general and in particular the ones in the Chirpan and Plovdiv areas in the spring of 1928 on the thermal and mineral waters in Bulgaria. Journal of the Bulgarian Society of Engineers and Architects 29 (1-2), 2-6 (in Bulgarian).

Shterev, K. 1964. Mineral Waters in Bulgaria. Nauka i Izkustvo, Sofia, 172 pp. (in Bulgarian).

Stoyanov, N. 2011. A model of the piezometric depression in the Neogene-Quaternary complex related to the construction of the first subway diameter in the central part of Sofia. Annual of the University of Mining Geology "St Ivan Rilski” 54 (1), 155-160 (in Bulgarian).

Stoyanov, N. 2019. Mathematical Modeling in Hydrogeology. Numerical 3D Models Using Finite-Difference Method. "V. Nedkov” Publishing House, Sofia, 246 pp. (in Bulgarian).

Trayanova, M., Hristov, V., Atanassova, R., Haslinger, E., Plank, O., Wyhlidal, S., Benderev, A. 2018. Potential of corrosion and/or deposition of solid phases in the thermal waters in the region of Sofia Valley, Bulgaria, depending on their chemical composition. Bulgarian Chemical Communications 50, Special Issue G, 28-33.

Vladeva, L., Kostadinov, D. (Eds). 1996. Bulgarian Potable Mineral Waters - Composition, Characteristics, Assessment and Health-Prophylactic Options. Part I. M-8-M KF. "Kontrast”, Sofia, 175 pp. (in Bulgarian). 